\title{
Prick-tests and serological tests in the diagnosis of allergic reactivity to enzymes used in washing products
}

\author{
M. J. HOW and G. W. CAMBRIDGE \\ Biology Division, Unilever Ressarch Laboratory, Colworth/Welwyn, Colworth House, \\ Sharnbrook, Bedford, Beds
}

\begin{abstract}
How, M. J., and Cambridge, G. W. (1971). Brit. J. industr. Med., 28, 303-307. Prick-tests and serological tests in the diagnosis of allergic reactivity to enzymes used in washing products. Standardized prick-test antigens for use in the detection of allergic reactivity to enzymes (Alcalase and Maxatase) used in washing products have been prepared. These materials contained all the potentially allergenic components of the crude enzyme preparations. Tests showed that these materials were more appropriate, as prick-test antigens, than the crystalline enzyme. The presence of reagin-mediated, immediate-type allergy in factory workers was confirmed by prick-tests and passive transfer tests. Sera from these subjects and controls contained enzyme-specific haemagglutinating antibody and gave precipitin-like reactions with solutions of Alcalase and Maxatase. The latter reaction involved serum components electrophoretically similar to, or identical with, $a$-globulins.
\end{abstract}

Skin-test procedures provide accurate, fundamental information on immunological phenomena in man, and may be used (Pepys, 1968) to demonstrate immediate, Arthus, and delayed type allergic reactions (types I, III, and IV; Coombs and Gell, 1968). Such methods (prick-tests and, occasionally, intracutaneous tests) have been used (Flindt, 1969; Pepys, Hargreave, Longbottom, and Faux, 1969; Greenberg, Milne, and Watt, 1970; Newhouse, Tagg, Pocock, and McEwan, 1970) to demonstrate type I allergy in factory workers following exposure to crude preparations of the proteolytic enzymes Alcalase $^{1}$ and Maxatase ${ }^{2}$ that are incorporated into certain washing products. The crude enzyme preparations, which are obtained by a fermentation process using Bacillus subtilis and related organisms, contain approximately $70 \%$ of sodium chloride and sodium sulphate and $30 \%$ of organic material

'Supplied by NOVO Industri A/S, Copenhagen, Denmark. 'Supplied by Royal Netherlands Fermentation Industries Ltd., Delft, Holland. which includes proteolytic and amylolytic enzymes, bacterial spores and cell debris, and components of the fermentation medium. Various workers have used, as prick-test antigens, extracts of the crude enzyme preparations, crystalline proteinases derived from such materials, and a commercial, crystalline proteinase ex B. subtilis, but these materials have not been defined in terms of proteolytic activity or protein content.

Serological tests for allergic reactivity to these enzymes have also been investigated. Pepys et al. (1969) demonstrated precipitins to extracts of Alcalase and Maxatase and to a crystalline proteinase ex $B$. subtilis in the sera of some subjects with a history of exposure to the crude enzyme preparations, but positive precipitin tests were obtained in a greater proportion of asthmatic and healthy subjects not working with these enzymes. Greenberg and his colleagues (1970) also found precipitins to enzyme extracts in the sera of 25 out of 43 subjects with positive prick-test reactions to the enzyme extracts, but other workers (Wüthrich and Ott, 1969; Franz, 
McMurrain, and Bernstein, 1970) were unable to demonstrate precipitins by immunodiffusion. The presence of reagin-mediated allergy in factory workers exposed to $B$. subtilis enzyme has been demonstrated by passive transfer tests (Franz et al., 1970) but attempts to demonstrate Alcalase-/ Maxatase-specific reaginic antibody $\left(I_{g} E\right)$, using the red cell linked antigen antiglobulin reaction, were unsuccessful (Newhouse et al., 1970).

We now report the evaluation of prick-test antigens and serological tests in the diagnosis of allergic reactivity to these enzymes.

\section{Materials and methods}

\section{Preparation and standardization of prick-test antigens}

Aqueous solutions of batches of Alcalase and Maxatase, produced in 1968 for use in Unilever factories, were separately dialysed, centrifuged, and freeze-dried. Serial dilutions of these extracts in saline were evaluated as prick-test antigens in order to ascertain a suitable concentration which was non-irritant but gave adequate wheal reactions in factory workers ${ }^{1}$ with a previous history of positive prick-tests to these enzyme preparations. On the basis of this preliminary evaluation, solutions of each of the dialysed enzyme preparations in sterile saline were prepared to contain approximately $500 \mu \mathrm{g}$ protein $/ \mathrm{ml}$ and were sterilized by filtration through a $0.22 \mu$ filter (Millipore). Aliquots $(0.5 \mathrm{ml})$ of the solutions, dispensed into ampoules under aseptic conditions, were freeze-dried and the ampoules were sealed. The material in an ampoule was reconstituted by adding $0.5 \mathrm{ml}$ sterile water immediately before use for prick-testing. A solution $(1 \mathrm{mg} / \mathrm{ml}$ ) of a crystalline proteinase ex $B$. subtilis (Koch-Light Labs. Ltd., batch no. 43573) in saline was sterilized by filtration and was dispensed into sterile bottles. Representative samples of the ampouled products and the solution satisfied the sterility requirements of the British Pharmacopoeia (Appendix XVII, 1968). At each stage in the preparation of the antigens the protein content (Lowry, Rosebrough, Farr, and Randall, 1951) and proteolytic activity (Weenan, 1969) were measured. Proteolytic activity is expressed in terms of glycine units, where 1 glycine unit is the amount of enzyme activity which, on incubation with acetylated casein under standard conditions, liberates amino groups equivalent to those contained in $1 \mu \mathrm{g}$ of glycine.

Evaluation of prick-test antigens: Prick-test procedure One drop of each solution and a control of sterile, physiological saline was placed on the washed and dried ventral surface of the forearm, and the epidermis was pricked once through the drop with a no. 20 needle without drawing blood. Excess solution was wiped off immediately and the arm was inspected 10 minutes later. A fresh ampoule of Alcalase or Maxatase was used for each batch of prick-tests to avoid the risk of using an opened ampoule which might have become contaminated or lost enzymic potency on storage.

Factory workers

Twenty-nine factory workers (identified in the text by numbers 1 to 29) used in this study either had a clinical ${ }^{1}$ Nos. 12, 14, 16, 24, and 28. history suggestive of allergic reactivity to the enzymes or had given a positive prick-test to Alcalase or Maxatase during routine medical examinations.

\section{Control group}

Eighty laboratory workers were used as controls in the evaluation of the Alcalase prick-test antigen. Forty-five per cent of this group gave positive prick-tests to one or more of the following common allergens: house dust mite extract (Dome), Aspergillus fumigatus, B2 grass pollens, and A1 mixed inhalants (Bencard). Nine of this group and 11 persons with no known contact with the enzymes were used as controls in passive transfer and precipitin studies.

\section{Serological studies}

Samples of blood from 12 of the 29 factory workers and 20 controls were obtained by venepuncture. Individual sera were used for passive transfer, haemagglutination, and precipitin studies, and pooled sera from 11 of these factory workers and from one control were separately fractionated by elution from Sephadex G-200 (Fahey and Terry, 1967). Fractions were concentrated by dialysis against carbowax, and the components in individual fractions were identified by immunoelectrophoretic analysis using anti-human serum raised in rabbits.

\section{Passive transfer tests}

Serum samples $(0.1 \mathrm{ml})$ from factory workers (nos. 5,8 , $10,13,17,18,19,21,22,25,27,29$ ), two pollen-sensitized subjects, and 20 controls were injected intradermally into baboons sedated with phenylcylidine. After 48 hours, $5 \%$ Pontamine sky blue $(1 \mathrm{ml} / \mathrm{kg}$ bodyweight) was injected intravenously and 5 minutes later $0.1 \mathrm{ml}$ of a non-irritant solution of the appropriate antigen was injected into the site of the previous intradermal injection. The reactions were scored over a period of 1 hour and, on the basis of the size and appearance of the reactions, were recorded as well-defined, strong positive, definite positive, weak positive, doubtful or negative.

\section{Immunodiffusion and immunoelectrophoresis}

The presence of Alcalase-/Maxatase-specific precipitins was investigated by immunodiffusion analysis at $4^{\circ}$ using $1 \%$ agar in $0.07 \%$ barbiturate buffer, $\mathrm{pH} 8.2$, and dialysed Alcalase and Maxatase (approx. $50 \mathrm{mg} / \mathrm{ml}$ in saline) as antigens. The electrophoretic mobility of serum components which gave precipitin reactions with Alcalase and Maxatase was determined by immunoelectrophoretic analysis using the gel described above. In all experiments the optimal concentration of antigen which gave a precipitin reaction was established by using serial dilutions of the antigen.

\section{Haemagglutination studies}

Defibrinated sheep erythrocytes without preservative (Wellcome Foundation Ltd., $5 \%$ suspension in $0.9 \%$ saline) were sensitized by treatment with an equal volume of a $0.2 \%$ solution of dialysed, freeze-dried Alcalase in saline at $37^{\circ}$ for 10 minutes. This was the maximal concentration of antigen which did not cause spontaneous lysis of the erythrocytes. Aliquots ( 2 drops) of $5 \%$ suspensions of washed, sensitized erythrocytes and of untreated erythrocytes were reacted with aliquots 
(5 drops) of serial dilutions of serum from factory workers (nos. 5, 8, 10, 13, 17, 18, 19, 21, 22, 25, 27, 29), from 20 controls, and from serum fractions obtained by chromatography on Sephadex G-200. The erythrocytes were examined for haemagglutination after 2 hours at $4^{\circ}$. Similar investigations were carried out using tannic-acidtreated erythrocytes (Boyden, 1951) that had been sensitized with Alcalase solution. The titres obtained in both types of haemagglutination test were corrected for the values obtained with unsensitized erythrocytes.

\section{Results}

The proteolytic activity and protein content of the antigens are summarized in Table 1.

\section{TABLE 1}

\section{Proteolytic Activity and Protein Content of Prick-test Antigens}

\begin{tabular}{l|r|r}
\hline \multicolumn{1}{c|}{ Antigen } & $\begin{array}{c}\text { Protein } \\
(\mu g / \mathrm{ml})\end{array}$ & $\begin{array}{c}\text { Proteolytic } \\
\text { activity } \\
(\text { glycine } \\
\text { units/ml })\end{array}$ \\
\hline $\begin{array}{l}\text { Alcalase, reconstituted ex ampoule } \\
\text { Maxatase, reconstituted ex ampoule }\end{array}$ & 600 & 500 \\
Proteinase ex B. subtilis & 1000 & 500 \\
& 12000 \\
\hline
\end{tabular}

\section{Comparison of prick-test antigens}

In a group of six factory workers, with a previous history of positive prick-test reactions to Alcalase and/or Maxatase, the skin-reactions obtained using a solution of the purified proteinase as prick-test antigen, were, with one exception, considerably smaller than those obtained with the standardized Alcalase (Table 2).

TABLE 2

Prick-test Reactions with Standardized Alcalase and Proteinase ex B. subtilis in FACTORY WORKERS

\begin{tabular}{|c|c|c|c|}
\hline \multirow{2}{*}{ Subject } & \multicolumn{3}{|c|}{$\begin{array}{c}\text { Size of wheal reaction }(\mathrm{mm}) 10 \text { min after } \\
\text { prick-test }\end{array}$} \\
\hline & Alcalase & $\begin{array}{l}\text { Proteinase } \\
\text { ex } \mathrm{B} \text {. subtilis }\end{array}$ & Saline \\
\hline $\begin{array}{r}20 \\
6 \\
7 \\
23 \\
3 \\
11\end{array}$ & $\begin{aligned} 4 & \times 4 \\
4 & \times 4 \\
4 & \times 4 \\
4 & \times 7 \\
3 \cdot 5 & \times 3 \cdot 5 \\
4 & \times 5\end{aligned}$ & $\begin{array}{c}0 \\
2 \times 3 \\
2 \times 2 \\
2 \times 2 \\
2 \times 2 \\
6 \times 6\end{array}$ & $\begin{array}{c}2 \times 2 \\
0 \\
0 \\
0 \\
0 \\
0\end{array}$ \\
\hline
\end{tabular}

Essentially similar prick-test reactions were elicited in six factory workers who were tested with standardized Alcalase and Maxatase during routine examinations (Table 3 ).
TABLE 3

Prick-test Reactions With Standardized Alcalase and Maxatase in Factory Workers

\begin{tabular}{|c|c|c|c|}
\hline \multirow{2}{*}{ Subject } & \multicolumn{3}{|c|}{$\begin{array}{c}\text { Size of wheal reaction }(\mathrm{mm}) 10 \mathrm{~min} \text { after } \\
\text { prick-test }\end{array}$} \\
\hline & Alcalase & Maxatase & Saline \\
\hline $\begin{array}{r}1 \\
2 \\
4 \\
9 \\
15 \\
26\end{array}$ & $\begin{array}{l}3 \times 3 \\
4 \times 4 \\
4 \times 4 \\
4 \times 4 \\
4 \times 4 \\
3 \times 3\end{array}$ & $\begin{array}{l}3 \times 3 \\
3 \times 3 \\
4 \times 4 \\
4 \times 4 \\
4 \times 4 \\
3 \times 3\end{array}$ & $\begin{array}{l}0 \\
0 \\
0 \\
0 \\
0 \\
0\end{array}$ \\
\hline
\end{tabular}

The reconstituted Alcalase antigen gave negative prick-test reactions in 80 control subjects, $25 \%$ of whom had worked in the laboratory with the crude or purified enzyme for up to three years. Forty-five per cent of this group were defined as atopic by virtue of positive reactions to one or more of the common allergens tested.

\section{Passive transfer tests}

Passive transfer of skin-sensitizing reaginic antibody to Alcalase was obtained with sera from 10 (nos. 5, $8,13,17,18,19,21,22,25,29)$ of 12 factory workers with a history of exposure to Alcalase and/or Maxatase and positive prick-test reactions to these enzymes. Positive passive transfer tests were also obtained with six of these sera (nos. 5, 8, 13, 18, 19, 29) using Maxatase as the challenge antigen. Four of the sera (nos. 8, 19, 22, 29) that contained Alcalasespecific reagin were re-tested six months later and gave essentially similar results. After heat-treatment $\left(56^{\circ}, 1\right.$ hour) of these four sera, the passive transfer reactions were negative in three cases and significantly reduced in the fourth case. Passive transfer reactions, using Alcalase as the challenge antigen, were negative with serum from each of 20 control subjects.

\section{Immunodiffusion and immunoelectrophoresis}

Immunodiffusion analyses using Alcalase and Maxatase as antigens showed at least two precipitin bands with all sera tested from 11 factory workers (nos. 5, 8, 10, 13, 18, 19, 21, 22, 25, 27, 29) and the 20 controls also used for passive transfer tests. There was no evidence that the precipitin systems in the factory workers were different from those in a control subject. Immunoelectrophoretic analyses of the same sera from factory workers and controls showed that, in all cases, the serum component(s) which precipitated with component(s) of Alcalase and Maxatase had a similar electrophoretic mobility to that of $a$-globulins. Precipitin reactions involving $\gamma$-globulins $\left(I_{g} G\right)$ were not detected in sera from factory 
workers or controls. Immunodiffusion and immunoelectrophoretic analyses of fractions obtained by elution of sera from Sephadex G-200 confirmed that precipitin reactions with Alcalase were confined to the fractions that contained $\alpha$-globulins.

\section{Haemagglutination studies}

The levels of haemagglutinating antibody that were detected in sera from many of the control subjects were higher than those present in sera from factory workers (nos. 5, 8, 10, 13, 17, 18, 19, 21, 22, 25, 27, 29). The results of the two types of haemagglutination test probably indicate that sera from these factory workers and controls contained antibodies specific for carbohydrate and protein components which are present in the crude enzyme preparation. Further investigations would be necessary, however, to confirm this. Analyses using serum fractions showed that the haemagglutinating antibody was preponderantly $\mathbf{I}_{\mathrm{g}} \mathbf{M}$.

\section{Discussion}

The presence, in the crude enzyme preparations, of several potentially allergenic components, including proteolytic enzyme, has prompted us to prepare, and to recommend the use of, prick-test antigens which would detect allergic reactivity to all of these components. Routine prick -tests are invaluable as a means of early diagnosis of allergy in subjects who may show no clinical symptoms of exposure to these enzymes and, in our experience, the solutions obtained on reconstitution of the standardized, ampouled preparations of dialysed and freeze-dried Alcalase and Maxatase are entirely adequate for this purpose. The use, in this context, of a solution of a commercial, purified proteinase ex $B$. subtilis was much less satisfactory, despite the fact that it contained almost twice as much protein as the Alcalase antigen, and was of greater enzymic potency. These results suggest either that the purified proteinase, as an antigen, is only partially similar to the proteolytic enzyme in crude Alcalase, and/or that components of Alcalase, other than the proteolytic enzyme, are antigenic in man. Studies of the antigenicity of such components are in progress in this laboratory. As crystalline proteinases derived from crude Alcalase and Maxatase represent only one antigenic component of the crude enzyme, we do not advocate the sole use of such materials as prick-test antigens. Allergic reactivity in humans following exposure to other proteolytic enzymes such as trypsin and chymotrypsin has been reported (MacLaren and Aladjem, 1957; Howe et al., 1961) and the reactions described in those reports show several similarities to those observed in workers exposed to Alcalase or Maxatase. In many of those cases, allergy resulted from exposure to highly purified enzymes, and the use of the crystalline proteinase as a skin-test antigen in that context was obviously most appropriate.

In our experience, the standardized Alcalase and Maxatase antigens have elicited no false-positive reactions in either atopic or non-atopic subjects. The essentially similar reactions that were given by Alcalase and Maxatase in the factory workers examined may indicate that these persons had been exposed to both types of crude enzyme preparation. Alternatively, Alcalase and Maxatase may be sufficiently similar antigenically to preclude differentiation of these antigens by prick-tests. It should be borne in mind that any changes in the source or manufacturing process that could lead to changes in the antigenic components of crude enzymes handled in factories should be taken into account in future prick-testing and appropriate antigens should be made available.

The ampouled, freeze-dried prick-test antigens are stable, sterile, spore-free, and convenient to use and distribute. The solutions obtained on reconstitution of these antigens are reproducible and their use should permit meaningful comparison of the results obtained by factory and government medical officers and dermatologists to whom these materials may be made available.

The results of passive transfer tests and prick-tests confirm other workers' findings (Franz et al., 1970) that some factory workers with a history of exposure to these enzymes show immediate-type reactions mediated by Alcalase-/Maxatase-specific reaginic antibody. Such reactions were not obtained in the group of control subjects. Our investigations show, however, that neither the precipitin-like reactions that occur between human serum and Alcalase and Maxatase nor the haemagglutination reactions are diagnostic of allergic reactivity to these enzymes, in so far that neither test differentiated between the factory workers we have investigated and controls. The precipitin reactions we have observed can be attributed to non-specific interactions between component(s) of the crude enzyme and serum components electrophoretically similar to, or identical with, $\alpha$-globulins. Pepys et al. (1969) reported that the precipitin reaction occurred with the $\gamma$-globulin component isolated by ion-exchange chromatography (Levy and Sober, 1960) from the sera of one affected factory worker, one asthmatic, and one control. We have found no evidence, however, for Alcalase-/Maxatase-specific precipitins of the $\gamma$-globulin type in sera from the 29 factory workers we have investigated or from controls.

The significance of precipitin-mediated reactions in subjects with allergic reactivity to the enzymes is uncertain. Only one case of a late skin-test reaction, similar to a precipitin-mediated, Arthus type (type III) reaction, has been reported following intra- 
cutaneous tests in such subjects (Pepys et al., 1969). Other workers (Flindt, 1969; Greenberg et al., 1970; Newhouse et al., 1970) did not detect late prick-test reactions in factory workers and we have received no reports of late reactions following pricktests with Alcalase and Maxatase. Immediate and late, mainly asthmatic, reactions were observed, however, following provocative inhalation tests (Pepys et al., 1969), and delayed pulmonary reactions were reported (Flindt, 1969) in factory workers exposed to the crude enzyme preparations. The cause of these late pulmonary reactions is unknown. Work is in progress to establish whether the precipitin-like complexes we have observed may be clinically significant in subjects with reagin-mediated allergy to the enzymes.

A number of proteinase inhibitors which are electrophoretically similar to, or identical with, $\alpha$-globulins have been identified in human serum (Vogel, Trautschold, and Werle, 1968). Recent work in this laboratory suggests that $a$-globulins from human serum which form precipitates with Alcalase or Maxatase also inhibit the proteolytic activity of these enzyme preparations. Chronic obstructive lung disease has been reported (Eriksson, 1970; Editorial, Lancet, 1970) in patients with a severe deficiency of the major normal serum- $\alpha_{1}$-globulin which inhibits trypsin and other proteases, and it is possible that the direct proteolytic action of Alcalase and Maxatase on the lung would be influenced by the anti-protease level in the individual. Further investigations of this situation are in progress.

We thank Dr. P. N. Cunningham, Chief Medical Officer, Unilever Merseyside Ltd., for his generous co-operation in these studies; Mrs. M. L. Maddy, Inveresk Research International (formerly Arthur D. Little Research Institute), Musselburgh, Midlothian, Scotland for passive transfer tests; and our colleague Dr. P. Porter for valuable discussion.

\section{References}

Belin, L., Falsen, E., Hoborn, J., and André, J. (1970). Enzyme sensitisation in consumers of enzyme-containing washing powder. Lancet, 2, 1153-1157.

Boyden, S. V. (1951). The adsorption of proteins on erythrocytes treated with tannic acid and subsequent hemagglutination by antiprotein sera. J. exp. Med., 93, 107-120.

Coombs, R. R. A., and Gell, P. G. H. (1968). Classification of allergic reactions responsible for clinical hypersensitivity and disease. In Clinical Aspects of Immunology, edited by P. G. H. Gell and R. R. A. Coombs, 2nd ed., Chapter 20, pp. 575-596, Blackwell Scientific Publications, Oxford.

Editorial (1970). Antitrypsin deficiency in chronic obstructive lung disease. Lancet, 1,71 .

Eriksson, S. (1970). Antitrypsin deficiency in chronic obstructive lung disease. Lancet, 1, 891-892.

Fahey, J. L., and Terry, E. W. (1967). In Handbook of Experimental Immunology, edited by D. M. Weir, p. 40,
Chapter 3. Ion exchange chromatography and gel filtration, pp. 19-43. Blackwell Scientific Publications, Oxford.

Flindt, M. L. H. (1969). Pulmonary disease due to inhalation of derivatives of Bacillus subtilis containing proteolytic enzymes. Lancet, 1, 1177-1181.

Franz, T. J., McMurrain, K. D., and Bernstein, I. L. (1970) Reaginic allergy in factory workers exposed to $B$. subtilis enzyme. Abstract No. 5. Annual Meeting American Academy of Allergy, New Orleans, 16-18 Feb. 1970 in $J$. Allergy, 45, 100.

Greenberg, M., Milne, J. F., and Watt, A. (1970). Survey of workers exposed to dusts containing derivatives of Bacillus subtilis. Brit. med. J., 2, 629-633.

Howe, C., Erlanger, B. F., Beiser, S. M., Ellison, S. A., and Cohen, W. (1961). Hypersensitivity to purified trypsin and chymotrypsin. New Engl. J. Med., 265, 332-334.

Levy, H. B., and Sober, H. A. (1960). A simple chromatographic method for preparation of $\gamma$-globulin. Proc. Soc. exp. Biol. (N.Y.), 103, 250-252.

Lowry, O. H., Rosebrough, N. J., Farr, A. L., and Randall, R. J. (1951). Protein measurement with the Folin phenol reagent. J. biol. Chem., 193, 265-275.

MacLaren, W. R., and Aladjem, F. (1957). Allergy to chymotrypsin. J. Allergy, 28, 89-90.

Monte, V., and Dolovich, J. (1970). Binding of the allergenic Bacillus subtilis proteinases with $\alpha_{2}$-macroglobulin. In International Congress Series No. 211, 7th International Congress of Allergology, Florence, Italy, 12-17 Oct. 1970, p. 14, Excerpta Medica.

Newhouse, M. L., Tagg, B., Pocock, S. J., and McEwan, A. C. (1970). An epidemiological study of workers producing enzyme washing powders. Lancet, 1, 689-693.

Pepys, J. (1968). Skin tests in diagnosis. In Clinical Aspects of Immunology, edited by P. G. H. Gell and R. R. A. Coombs, 2nd ed., Chapter 7, pp. 189-220. Blackwell Scientific Publications, Oxford.

- Hargreave, F. E., Longbottom, J. L., and Faux, J. (1969). Allergic reactions of the lungs to enzymes of Bacillus subtilis. Lancet, 1, 1181-1184.

Radermecker, M. (1970). Derronstration d'anticorps réaginiques (IgE) et précipitants (IgG) dans le sérum d'un patient allergique aux enzymes protéolytiques du Bacillus subtilis. International Congress Series No. 211, 7th International Congress of Allergology, Florence, Italy, 12-17 Oct. 1970, p. 11, Excerpta Medica.

Vogel, R., Trautschold, I., and Werle, E. (1968). Natural Proteinase Inhibitors. Academic Press, New York and London.

Weenan, J. H. M. (1969). Enzyme analysis: a rapid automated method. Proc. chem. Spec. Mfrs. Ass., Dec., pp. 109-112.

Wüthrich, B., and Ott, F. (1969). Berufsasthma durch Proteasen in der Waschmittelindustrie. Schweiz. med. Wschr., 99, 1584-1586.

\section{Addendum}

Belin, Falsen, Hoborn and André (1970) reported three cases of type I allergic reactivity to Alcalase, with serological evidence for enzyme-specific IgE but no serological indication of a precipitin-mediated, Arthus (type III) reaction. A non-immunologic precipitin reaction involving human $\alpha_{2}$-macroglobulin and $B$. subtilis protease has been reported by Monte and Dolovich (1970). Radermecker (1970), however, found enzyme-specific $\mathrm{IgE}$ and IgG in serum from one person allergic to $B$. subtilis enzymes.

Received for publication August 22, 1970 